\title{
Assessing nitrogen dynamics in European ecosystems, integrating measurement and modelling: conclusions
}

\author{
A.J. Wade ${ }^{1}$, C. Neal ${ }^{2}$, D. Butterfield ${ }^{1}$ and M.N. Futter ${ }^{3}$ \\ ${ }^{1}$ Aquatic Environments Research Centre, University of Reading, Reading, RG6 6AB, UK \\ ${ }^{2}$ Centre for Ecology and Hydrology, Crowmarsh Gifford, Wallingford, OX10 8BB, UK \\ ${ }^{3}$ Environmental and Resource Studies, Trent University, Peterborough, ON K9J 7B8, Canada \\ Email for corresponding author: a.j.wade@reading.ac.uk
}

\begin{abstract}
This contribution closes this special issue of Hydrology and Earth System Sciences concerning the assessment of nitrogen dynamics in catchments across Europe within a semi-distributed Integrated Nitrogen model for multiple source assessment in Catchments (INCA). New developments in the understanding of the factors and processes determining the concentrations and loads of nitrogen are outlined. The ability of the INCA model to simulate the hydrological and nitrogen dynamics of different European ecosystems is assessed and the results of the first scenario analyses investigating the impacts of deposition, climatic and land-use change on the nitrogen dynamics are summarised. Consideration is given as to how well the model has performed as a generic tool for describing the nitrogen dynamics of European ecosystems across Arctic, Maritime, Continental and Mediterranean climates, its role in new research initiatives and future research requirements.
\end{abstract}

Keywords: nitrogen, nitrate, ammonium, phosphorus, catchments, streams, rivers, river basins, EU-INCA, Euro-limpacs

\section{Introduction}

Nitrogen is a key nutrient for sustaining life on Earth. However, excess nitrogen in a river system can have a detrimental effect and the 'reactive nitrogen', (i.e. that which is biologically active in the environment) presently being cycled exceeds that from pre-industrial natural processes by about $80 \%$ (www.nerc.ac.uk/funding/thematics/gane/ description.shtml). Excess reactive nitrogen is derived primarily from fertiliser applications, animal waste and fossil fuel combustion; it contributes to eutrophication, reduced plant diversity, soil and streamwater acidity, and enhanced emissions of $\mathrm{NO}_{x}$ to the atmosphere (Burt et al., 1993; Wright and Rasmussen, 1998a,b). Since excess nitrogen is the by-product of agriculture, power-generation, industry and transport, then measures introduced to reduce the effects of nitrogen pollution must be considered in conjunction with the likely economic consequences. Against this backdrop, it is becoming increasingly important to quantify the effects of excess nitrogen on ecosystem function and health (Likens, 2004).
The factors and processes controlling the storage and transfers within the nitrogen cycle and the potential impacts on the environment are relatively well understood. However, the quantification of the nitrogen mass stored and transported in the soil, groundwater, rivers, lakes, estuaries, oceans and air remains uncertain, as does the quantification of the ecological impact. This uncertainty arises because of an inability to extrapolate nitrogen flux or measurements of concentrations made in the laboratory or at a single-point in the field to larger spatial units due to the spatial and temporal heterogeneity in the factors controlling the nitrogen processes. Also, given that the sources of nitrogen are multiple, in areas such as large $\left(>100 \mathrm{~km}^{2}\right)$ river systems, linking a pollution problem to a particular source is difficult as measurements made today may reflect the pollution history, rather than the current nitrogen sources.

Mathematical models of the nitrogen sources, sinks and transport mechanism provide tools with which to test hypotheses of system functioning, and provide a means of quantifying the impacts of a pollutant load on the 
environment based on well-defined, if sometimes questionable, assumptions. As a result of many national and international research initiatives, a broad range of nitrogen models has been developed commensurate with the different aspects of nitrogen pollution (such as nitrogen leaching from forests, grassland and arable dominated systems, soil and stream water acidification, within-river and -lake eutrophication and gaseous emissions) and data availability.

This paper summarises the results of the science in this and in a previous Special Issue of Hydrology and Earth System Sciences (Volume 6, Issue no. 3, 2002), dedicated to assessing nitrogen dynamics in catchments across Europe within a modelling framework. This second volume is focused on the continuing development and testing of INCA, a semi-distributed Integrated Nitrogen model for multiple source assessment in Catchments (Whitehead et al., 1998a,b; Wade et al., 2002a) in the context of a major initiative dealing with the prediction and management of aquatic nitrogen pollution across Europe (Wade et al., 2002b). Also, the results of further modelled scenarios are reported, which quantify the likely impacts of deposition, climatic and landuse changes on the nitrogen dynamics in river systems and build on the first scenarios run for UK systems (Limbrick et al., 2000; Flynn et al., 2002; Jarvie et al., 2002; Skeffington, 2002). The initiative was originally sponsored by the European Union under the project Integrated Nitrogen Model for European Catchments, contract number EVK11999-00011, and will continue as part of the EU 6th Framework 'Euro-limpacs' Integrated Project, contract no. GOCE-CT-2003-505540 (www.eurolimpacs.ucl.ac.uk).

\section{Regional water quality}

The water quality functioning of catchments has been examined in great detail across Europe over the last 30 or more years. This is in recognition of the regional dimensions to the problems of $\mathrm{N}$ in the aquatic environment with, in some cases, long time-scales for recovery and clean-up involved (Heathwaite et al., 1993; Stanners and Bourdeau, 1995; Langusch and Matzner, 2002a, b; Skeffington, 2002). A large literature on the environmental issues across Europe is available (Wright and Rasmussen, 1998a,b; Burt et al., 1993; Neal et al., 2002). Many types of ecosystem and issues are involved (Stanners and Bourdeau, 1995); they cover a wide range of typologies linked to

- Climate; sub-arctic to Mediterranean and from Atlanticmaritime to central-continental.

- Pollution-climate: especially applicable in the case of acidic oxide emissions and ammonia generation from farming activities.
- Land use: near-pristine grasslands/forests to plantation forests, to agricultural areas to urban/industrial systems.

The extent of climate variability and climate instability, associated with global climate change, is considerable across Europe, affecting:

- temperature and light cover that affect biological and chemical functioning of catchments.

- the relative importance and distribution of wet deposition and snow.

- large ranges in annual rainfall volumes, evaporation loss and flows in rivers and lakes.

- contrasting intensity and distribution of rainfall.

- cases where stream flow ceases or reduces substantially under the conditions of extremes of cold or aridity.

- heterogeneity of many of the systems being examined.

- the relative importance of near-surface runoff and aquifer supplies for rivers and lakes.

Together, climate, the variability in $\mathrm{N}$-inputs and the land use determine nitrogen dynamics within rivers and lakes. The dynamics represent an interplay of these factors with inorganic and, most often, organic processes within:

- the vegetation canopy;

- the soil, groundwater, wetland areas;

- the river where nitrogen fluxes and chemical speciation are changed.

Within this and the earlier Special Issue of Hydrology and Earth System Sciences linked to $\mathrm{N}$ issues across Europe, the focus has been on rivers rather than lakes. Here, it is only the riverine systems that are considered: due to volumetric storage, lakes often show a less dynamic response to $\mathrm{N}$, but within-lake processing of $\mathrm{N}$ can modify the distribution of $\mathrm{N}$ over both space and time. The case studies for rivers are for the:

- Scandinavia and the Baltic states (Kaste and Skjelkvåle, 2002; Rankinen et al., 2002; Vagstad et al., 2004);

- The Netherlands (Tietema et al., 2002; Raat et al., 2002).

- Germany (Langusch and Matzner, 2002a, b);

- United Kingdom (Fisher and Acreman, 2004; Hill, 2000; Jarvie et al., 2002; Kennedy and Murphy, 2004; Limbrick, 2002; Machefert et al., 2002; Machefert and Dise, 2004; Neal, 2002a, b; Neal et al., 2004a, b; Snook and Whitehead, 2004; Whitehead et al. 2002a, b);

- France (Ruiz et al., 2002a, b);

- Spain (Avila et al., 2002; Butturini and Sabater, 2002; Butturini et al., 2002; Gallart et al., 2002). 
The catchment studies presented in this special issue, coupled with associated material, show broadly five groupings linked to ranges in average nitrate levels (Neal et al., 2002):

- 0 to $150 \mu \mathrm{g}-\mathrm{N}^{-1}$. This range applies to the most pristine areas with low atmospheric nitrogen contamination or areas with high biological uptake of atmospheric inputs of pollutant nitrogen.

- 150 to $400 \mu \mathrm{g}-\mathrm{N}^{-1}$. The averages in this range occur in relatively undisturbed areas with some atmospheric nitrogen contamination.

- 400 to $2000 \mu \mathrm{g}-\mathrm{N}^{-1}$. This range applies to rural catchments. The concentrations in this group increase with agricultural and population inputs.

- 2000 to $8000 \mu \mathrm{g}-\mathrm{N}^{-1}$. These concentrations occur as agricultural inputs and urban/industrial sources become much more important.

- 8000 to over $20000 \mu \mathrm{g}-\mathrm{N}^{-1}$. These concentrations occur where there is major urban/industrial or agricultural contamination and where potential for dilution is low.

Within this Special Issue, there has been a greater focus on the nature of the agricultural and urban/industrial inputs to rivers (Neal et al., 2002; Snook and Whitehead, 2004). These groups are usually classified in terms of diffuse and point sources, respectively. However, there is a third important class, intermediate between point and diffuse sources, termed point-diffuse sources (Neal et al., 2004b).

\section{Diffuse sources}

For the agricultural supplies of N, diffuse pollution is associated with fertiliser and farm-waste being leached from the soils during rainfall/snow-melt and transferred either to river or ground water according to the level of water catchment storage at the time.

- With low catchment storage, then concentrations are expected to increase broadly in line with flow unless there are issues of exhaustion of supplies or within river loss of $\mathrm{N}$.

- Where aquifer storage is involved, a more damped signal is to be expected within the river waters due to aquifer buffering because of the high volume of storage. However, in this case, long-term changes in river water quality can occur: the chemistry of the groundwater changes as a function of the long-term changes in fertiliser inputs.

\section{Point sources}

These come from sewage treatment and industrial effluents discharged directly into the river. Streamwater concentrations decrease with increasing flow if the $\mathrm{N}$ concentration within the effluent is significantly higher than in the uncontaminated river.

\section{Point-diffuse sources}

These sources are associated with near-river inputs. They relate primarily to agricultural catchments where there are localised pollutant sources that enter the unsaturated zone and groundwater is available to be flushed into the river when groundwater flow and level increase in response to a rainfall or snow-melt event. These localised inputs are primarily associated with sewage effluent from sewage treatment works and septic tanks being discharged to groundwater rather than to the river and farm slurry waste. The $\mathrm{N}$ concentrations increase in the river with increasing flow if (a) the $\mathrm{N}$ concentration within the effluent is of significantly higher concentration than the groundwater and (b) exhaustion of pollutant does not occur during the hydrological event.

Within this special issue, the heterogeneous nature of nitrogen fluxes within regions is identified in the Nordic and Baltic States (Vagstad et al., 2004) and four papers relate to a key part of the catchment for attenuating $\mathrm{N}$ : these are wetland and riparian areas. These papers show:

- the potential importance of wetlands, swamps and marshes for removing both $\mathrm{N}$ and $\mathrm{P}$ (Fisher and Acreman, 2004). This is important in the context of pinning down the key areas where nitrogen loss occurs within catchments and to focus attention on environmentally friendly and sustainable approaches to managing catchments in respect of $\mathrm{N}$.

- that riparian zones can be important for nitrous oxide generation and denitrification processes; algorithms have been produced that are valuable for the modelling studies (Machefert and Dise, 2004). This work builds on the Machefert et al. (2002) study which sets the work in a European context. They show that nitrous oxide is an important greenhouse gas, generated from soils and dependent on available mineral nitrogen, soil temperature and water content, available organic compounds and land use.

- an important bio-indicator for assessing wetland ecosystem health (Kennedy and Murphy, 2004).

- the potential for pollution in near-river areas from pointdiffuse sources (Neal et al., 2004b).

With respect to water quality functioning of catchments across Europe, the work presented in this and the earlier volume indicates: 
- increases in nitrate and ammonium loading to catchments due to increased atmospheric deposition of pollutants from agriculture and industry, from the excessive use of nitrogenous fertilisers by agriculture and from urban and industrial discharges;

- that critical loading of nitrogen in acid-sensitive catchments is very important in relation to factors such as climate variability, changing patterns of acidification and land use change;

- that contamination by nitrates of river and ground waters may lead to problems of eutrophication and excessive weed and algal growth within rivers, affecting agricultural and urban/industrial areas;

- the potential importance of wetland and riparian areas for attenuating $\mathrm{N}$ within catchments.

\section{INCA development and application}

Wade et al. (2002a) describe the modifications made to the original INCA model by Whitehead et al. (1998a), to extend its applicability to a variety of catchment types and pollution issues. The INCA model was refined in relation to hydrology, as well as to climate controls on the biological processes of nitrogen attenuation. These refinements relate to soil-water retention volumes, soil moisture and temperature controls on process parameters and vegetation growth periods.

Building on these developments, INCA has been further refined for application in river systems that are snowcovered for part, or all, of the year. A new soil temperature response function and parameter temperature dependency function have been added to account for the snow blanket effect and cessation of soil microbial processes below observed threshold temperatures (Rankinen et al., 2004a, b). These modifications improve the simulations of soil temperature in cold climate regions, and thereby improve the simulation of soil $\mathrm{N}$ processes and peak streamwater nitrate concentrations.

Two further papers report on the ability of INCA to represent catchment nitrogen dynamics throughout Europe. The first application aimed to simulate the hydrology and nitrate dynamics of the Savijoki catchment, a small $\left(15 \mathrm{~km}^{2}\right)$ river system draining mainly agricultural land in Finland (Granlund et al., 2004). The second, in NE Spain, aimed to simulate the hydrology, nitrate and ammonium dynamics of the Mediterranean Fuirosos catchment $\left(10 \mathrm{~km}^{2}\right)$ (Bernal et al., 2004). In both applications, the model was able to reproduce the seasonal flow and nitrate concentration dynamics observed in the stream. In the Finnish application, the model also simulated the inter-annual variation in the flows and nitrate concentrations adequately. However, in the Fuirosos catchment, model re-calibration was necessary to simulate the nitrogen dynamics for wet and dry years. In Mediterranean systems in summer, runoff events tend to be short-duration, high-intensity convective storms over dry soils so that the runoff is restricted to largely poorlypermeable, rocky areas of the catchment, resulting in a flashy hydrograph and low peak flow rates (Gallart et al., 2002). Currently, INCA uses an estimate of the hydrologically effective rainfall which is based on the concept of saturation excess overland flow. It is now apparent that the concept of infiltration excess overland flow, and variable hydrological source areas, which can become decoupled from the stream during dry periods, must be incorporated to simulate the hydrological dynamics of Mediterranean systems.

Swamps, marshes and riparian zones can be important in controlling the in-stream nitrogen dynamics, particularly under storm-flow conditions (Lischeid and Langusch, 2004), and the majority of wetlands reduced nutrient loading (Fisher and Acreman, 2004). However, some wetlands increase nutrient loadings by increasing the loading of soluble $\mathrm{N}$ and $\mathrm{P}$ species, thus potentially driving aquatic eutrophication. Studies conducted over a year or more, or that involved frequent sampling, or sampling during high flow events, were more likely to conclude that the wetland increased nutrient loadings. Currently, wetlands are not considered explicitly in the INCA model, although to account for riparian zone denitrification, the riparian zone can be simulated by including it in the stream cell. Thus, the reach parameters are fixed so that the volume of water stored in the reach includes both the riparian zone and the stream (Durand, 2004).

Given the need to simulate nitrogen and phosphorus storage and transport in the lowlands of England, which, draining Chalk or Ssandstone, are predominantly groundwater-dominated, a new conceptual model has been developed (Neal et al., 2004b) to account, specifically, for the 'near-stream' zone, and the vertical movement of a solute through the unsaturated zone in Chalk. Initially, it is proposed that the chemical input to the stream from the nearstream zone is modelled using a regression equation to capture the behaviour of increased flow with flushing and then a subsequent exhaustion of supply. If such behaviour proves to be an adequate representation of what is observed in the stream, the natural extension is to create a processbased formulation.

The in-situ field studies and literature review of Machefert and Dise (2004) has shown that denitrification is related exponentially to soil moisture, with a rapid increase in denitrification rate at a water-filled pore space of between 60 to $80 \%$. Whilst denitrification flux is dependent on other factors, such as mineral nitrogen, soil temperature, the availability of organic components and land-use, as a first 
approximation, this result suggests that denitrification rates can be modelled simply by using an exponential relationship between denitrification potential and water-filled pore space (or volumetric/gravimetric water content) multiplied by a constant value determined by the nitrogen status of the site. This is an important result, which can be used in future developments of INCA, or in other models of the nitrogencycle, to estimate denitrification fluxes from the riparian zone.

In each model application, parameter equifinality occurred leading to considerable uncertainty in the model parameter values and the simulated nitrogen concentrations and loads. Combining synthetic datasets of soil and streamwater $\mathrm{NO}_{3}$ and $\mathrm{NH}_{4}$ concentrations and net mineralisation and nitrification loads in a multi-objective calibration was found to be an effective way to deal with the equifinality problems due to measurement uncertainty (Raat et al., 2004): multiobjective calibrations resulted in lower parameter uncertainty. This result echoes the call by Kirchner et al. (2004) for the collection of high-frequency multiplechemical data-sets to:

1. Determine the chemical provenance.

2. Characterise the catchment-scale retardation of solutes with respect to discharge.

3. Identify the data with which to develop and test the next generation of hydrochemical models.

The ability of the INCA model to simulate hydrology and nitrogen dynamics in the sub-Artic, Maritime, Continental and Mediterranean climates of Europe is discussed in detail in Wade et al., (in press), including a table of correlation co-efficients and co-efficients of efficiency/determination which quantify the fit of the simulated discharge and nitrate dynamics to those observed in model applications to sites throughout Europe. The model applications suggest that the data requirements and structural complexity of the INCA model are appropriate to simulate the key factors and processes controlling the seasonal and inter-annual flow and nitrate dynamics in Maritime and Continental Europe and, therefore, the annual nitrogen fluxes across a wide range of freshwater environments (Neal et al., 2002). Ammonium concentrations are not simulated well by INCA, since the nitrogen version does not include a sediment sub-model.

\section{Modelling the impacts of global change}

INCA has been used previously to investigate the impacts of land use and climatic change. The studies highlighted:
- Hydrological patterns in groundwater-dominated catchments in SE England will change with lower late summer flows and high winter flows and will undoubtedly affect the in-stream chemistry and biology (Limbrick et al., 2000; Wade et al., 2002c).

- Land-use change in a catchment can alter the streamwater nitrogen concentration profile significantly. For example, the transition from pasture to arable agriculture in the River Tweed is commensurate with a four-fold increase in streamwater nitrate concentration (Jarvie et al., 2002).

- Land-use change over time can affect nitrogen concentrations. The predominance of pasture land in the River Kennet would result in lower streamwater nitrate concentrations than those observed today, as the Kennet now drains a larger proportion of arable land (Whitehead et al., 2002a).

- Conversion from arable land to ungrazed vegetation (e.g. set-aside, pasture or woodland) may result in substantial reductions in nitrogen (Flynn et al., 2002).

- Buffer strips may be less successful in reducing nitrate in river systems dominated by urban drainage and effluent inputs (Flynn et al., 2002).

In the new scenario studies reported in this issue, INCA was applied to investigate changes to the $\mathrm{N}$-cycle in the cold climates of Norway and Finland in response to likely precipitation, temperature and deposition changes, to afforestation in Denmark and to climate-change and crop rotation in western France. The key results are:

- In Norway and Finland, the model scenario results suggest that climate-change and $\mathrm{N}$ deposition effects will largely cancel each other, though more frequent floods during winter will replace the regular snowmelt flood in spring (Kaste et al., 2004).

- Afforestation can have a protective function, reducing $\mathrm{N}$ leaching from former agricultural land (Bastrup-Birk and Gundersen, 2004).

- A $40 \%$ reduction in fertiliser combined with the introduction of catch crops is necessary to stop the degradation of water quality in rural catchments of western France (Durand et al., 2004).

Together, these results provide a preliminary assessment of the likely impacts of global change on the streamflow and nitrate concentrations in particular regions of Europe, and indicate that INCA is indeed a useful tool for evaluating nitrogen controls and processes in catchments. Moreover, these results will form the foundation for the modelling assessment of the impacts of global change on nutrient 
cycling and the associated biological response within the new Euro-limpacs project.

The scenario results also highlight the need to consider the unique characteristics of the nitrogen sources and catchment attributes (Beven, 2000) and suggest that, whilst 'blanket' strategies for nitrogen reduction may be easier to implement at the national and European scale than instruments targeted at individual polluters, it is necessary to ensure that the key pollutant source in each system is identified using data and modelling assessments, and then targeted appropriately. This procedure is complicated since the presently observed pollutant effect may result from historic pollutant loading in addition to the current inputs and, therefore, any attempt to implement a 'polluter-pays' approach must consider the pollution history. One practical measure to help farmers to implement Best Management Practice is proposed by Hewett et al., (2004), whose Nutrient Export Risk Matrix (NERM) allows farmers to explore ways of farming to minimise nutrient loss.

\section{Diversity in approach and a model hierarchy}

To predict nitrogen fluxes from individual European catchments, a diversity of modelling approaches is recommended. Even though INCA has been developed as a generic approach readily transferable between European systems, the need for diversity arises for three reasons.

Firstly, there is a need to compare the simulated outputs from the INCA model with other, complementary models of the $\mathrm{N}$ cycle, to confirm that the system is modelled adequately. The structure of INCA represents only one conceptualisation of how the system may function. In particular, it will be informative to compare the INCA predictions for component landscape units with those of models focused on single component types, such as forestry, arable land or pasture (Scholefield et al., 1991; Smith et al., 1996, Tietema, 2004). The comparison of INCA with an Artificial Neural Network has already demonstrated the need to consider the riparian zone (Lischeid and Langusch, 2004).

Secondly, the predicted response to global change derived using INCA must be compared with that from other models, applied at both the catchment and field scales, to determine the range of predicted behaviour using different model structures and parameter sets and, thereby, help overcome parameter and structural uncertainty. Kros et al. (2004) give an example of this approach: a regression equation, and two process-orientated dynamic-models WANDA (a regional nitrogen model With Aggregated Nitrogen DynAmics; Tietema, 2004) and SMART2 are used to estimated nitrate leaching on a national scale. All three methods show that, despite the high nitrogen inputs, Dutch forests still accumulate more nitrogen than they release. This implies that, from the point of view of groundwater quality, current nitrogen deposition is higher than the (long-term) critical loads.

Thirdly, though INCA can be adapted through the intelligent use of the current model structure or the reformulation of the model equations, it is still predominantly focused on rivers. As an alternative to developing a single generic approach, contemporary studies have investigated linking existing modelling approaches into chains to simulate river catchments, including wetlands and lakes (Boorman, 2003). The approach of linking models has the advantages that the component models are (a) developed at the appropriate scale, (b) commensurate with the available data and (c) being applied to address a specific issue. The output from each model can then be integrated to provide an overall simulation of the catchment flux delivery. However, at present, such approaches are still at the very early stages of development, though the Euro-limpacs project will focus on the integration of different water quality models to predict nutrient transfer and retention within river systems, including lakes and fjords; and will, therefore, take this idea forward.

As a minimum to apply INCA the following data are necessary:

- daily time series of hydrologically effective rainfall, soil moisture deficit and air temperature;

- spatial distribution of land use;

- the amount and timing of fertiliser applications (can be specified as an annual total over a fixed number of days);

- the growing seasons for different crops;

- an estimate of the relative contribution from soil- and ground water;

- inputs from atmospheric deposition either measured or modelled;

- observed flow and water chemistry data to calibrate the model to;

- any effluent inputs in terms of flow and concentration;

- process load estimates for the different land use types; these can be derived from the literature.

The data listed were generally available throughout the eight countries involved in EU-INCA. Other simpler approaches based on steady-state, such as the Export Coefficient Method (ECM), could be applied as an alternative to INCA where the need is to simulate regional- or nationalscale annual nutrient fluxes, or only limited data are available (Johnes, 1996). The ECM approach is based on the area of different land uses, land management practices, effluent 
discharges and observed water chemistry. Methods based on Geographical Information System (GIS) analysis can also be used to examine the distributions of nitrate, nitrite and ammonium at various monitoring sites across large (approximately $24000 \mathrm{~km}^{2}$ ) regions (Davies and Neal, 2004). Thus, in determining the key pollutant sources at the European scale, it may be most appropriate to operate a modelling hierarchy where simpler steady-state or GISbased methods are applied initially at large spatial scales to identify the nutrient hot-spots and likely main pollution sources. Following the identification of particular issues in certain catchments, intermediate-complexity process-based models, such as INCA, could then provide a more detailed assessment of the relative inputs from different pollutant sources, to investigate the options for reducing the pollutant inputs.

\section{Future directions of the INCA software: from the model to a modelling framework}

Almost nothing has been written of the actual INCA software code, yet the development of this code represents an advance in environmental modelling. Until very recently, the majority of environmental models tended to have limited graphical output and parameter files which had to be modified using a text editor and then reloaded into the model. The original INCA software was developed in 1995 and ran under DOS. The current version of INCA is a suite of programs with extensive graphics running under Windows. Currently, this suite includes the original nitrogen version (INCA-N), and new models which simulate phosphorus (INCA-P, Wade et al., 2002d), sediment, tritium and conservative pollutant dynamics in river systems. The software is highly professional allowing the user to load data, adjust parameters and view and save model output from a graphical user interface. Moreover, the model runs quickly, typically able to solve process equations for the land and in-stream components of a river system with 22 reaches (6 land-use types, on a daily time-step for 7 years) in under 30 seconds on a desktop computer with 512 Mbytes RAM and a 1.8 $\mathrm{GHz}$ processor. During the INCA project, just as the INCA model structure has evolved, so too has the software code. This section of the Conclusions highlights the exciting possibilities for environmental models now possible through utilising the latest coding techniques.

The suite of INCA models has developed as a mixture of procedural and object-oriented code in $\mathrm{C}$ and $\mathrm{C}++$. However, the long history of rapid development of the INCA-N model, as well as the creation of new versions for other determinands (e.g. INCA-P) has led to code that is increasingly difficult to maintain, due to the variations in the model structures, parameter sets and required input data between versions. As the INCA suite of models is further developed to model the behaviour of other chemicals (including DOC and $\mathrm{Hg}$ ) in new and different landscapes, greater flexibility in the design of the software is desirable. This greater flexibility is required to simulate tributaries and networks of lakes and streams and landscapes different from those already studied, including the Canadian Shield and complex groundwater environments (Neal et al., 2004b). Increased flexibility in the software is also required to add and evaluate process equations rapidly, as often the chemical cycling of the determinand of interest is poorly understood, and to allow model chaining. Given these software requirements, there is a need for a more generic programming approach to improve maintenance of existing models and to speed new model development. Thus, a new generic, object-oriented framework for environmental modelling is being designed, which can define and implement new model structures rapidly.

The main advantage of modern object-oriented design and programming methods in environmental modelling is that the fundamental building blocks of a conceptual model may be translated directly to code. This naturally breaks down complex conceptual environmental models into more manageable components. For example, a hydrological store can be represented by a compartment object, called 'store', containing collections of equation objects, which in turn define the processes. Instances of the object 'store' can be created to describe the soil water, groundwater or river-reach compartments within INCA.

Using well-defined object-oriented approaches, the management of the links between objects can be automated to reduce the code development and maintenance. Data flow to and from the model, and between the model compartments, can be managed with an additional, flexible time series object which acts not only as a container for data but can also provide mechanisms to allow the generation of time series. This generation could simply be to repeat a constant value, or to produce a time series from various distribution types or interfacing with external software such as Microsoft Excel or a relational database. In practical terms, this would mean the ability to infill monthly timeseries (e.g. of effluent concentrations or fertiliser inputs) to provide a daily time series, or to allow parameter values to vary during the model run. Through inheritance and polymorphism, these basic objects which define the building blocks of modelling (i.e. the hydrological and chemical stores, transport mechanisms and input and output data) can be used to derive systems of varying complexity, covering 
a large range of temporal and spatial scales and, hence, become a true framework.

The capability to generate new model structures and reformulate process equations rapidly will allow Functional Unit Networks to be developed (Neal, 1997), thereby facilitating the method of incorporating heterogeneous behaviour within a modelling structure where the question of parameter identification becomes of second order importance compared with examining the range of scenarios produced by various modelling structures. This development is needed to move towards assessing structural rather than parameter uncertainty, and to gain some feel for the range of likely environmental impacts. This contrasts with current analysis based on parameter uncertainty which starts with the assumption that the model is correct and the parameter distribution is unknown.

The design of the new modelling framework will be formalised using the Unified Modeling Language (UML), which is used to design the software architecture of the framework prior to coding. An Extensible Markup Language (XML) schema of the generic modelling framework will then be created to permit documentation and exchange of specifications between models: inputs and outputs. In this sense, a document is not only a traditional document, like this paper, but also other XML 'data formats', including vector graphics, mathematical equations and object metadata. An initial implementation of the framework will be developed in $\mathrm{C}++$ and $\mathrm{C} \#$ using the Microsoft .NET software development environment. The .NET environment allows the programmer to integrate code written in multiple programming languages, including FORTRAN. In addition, it allows some of the modelling framework functionality to be exposed for use in external software and supports the use of XML to format the input and output files. This flexibility should provide opportunities for results and model schema to be presented in a variety of media, which is important for the efficient chaining of existing and new models.

Initial investigations suggest it should be a relatively simple matter to reproduce any of the current major models using this framework: the framework can be used to specify and implement steady state models including the Export Coefficient Model (Johnes, 1996) or the Lakeshore Capacity Model (Dillon et al., 1994) and dynamic models such as MAGIC (Cosby et al., 1985) and IHACRES (Jakeman and Hornberger, 1993). The first application of the new framework will be the development of a new model, INCADOC which will simulate the production and transport of dissolved organic carbon at the catchment scale. This model is a very exciting prospect in itself and provides a great opportunity to investigate the utility of the modelling framework. The next planned application of the framework is an implementation of the Ontario Lakeshore Capacity Model, a steady-state lake eutrophication model. Subsequent to this, an implementation of IHACRES is planned. If this is possible, it will show the value of the framework for chaining model results as INCA-DOC relies upon IHACRES for its hydrological inputs. As a final test, the framework will be used to develop and unify the next generation of the INCA-N and INCA-P models.

The model framework creates potential for some interesting studies: for example, the model structure may be tested by altering the number of compartments and their links during a Monte Carlo simulation. The ability to allow parameter values to vary during each model simulation is intriguing since this, when coupled with General Sensitivity Analysis, would allow the modeller to investigate the most appropriate model structure to simulate the seasonal, or even storm-event, components of a flow or chemical time-series rather than just the system behaviour over the entire simulation period. In addition, the equations used to define a process can be changed easily. Thus, as scientific understanding changes, the models can be changed also.

The use of XML and the generation capabilities of the times series class also suggest intriguing possibilities for model chaining. If formal specifications of models are stored as XML schema and the framework is able to reproduce a conceptual model from a schema, there is no reason why a time series generation method cannot simply be another model. This would allow different models effectively to be 'plugged-in' at any point to produce inputs to compartments. It should be stressed that this is a programming framework and as such is aimed at programmers with a sound grasp of object-oriented techniques. In the future, however, the framework could be encapsulated as a true development environment, allowing models to be created interactively via a Windows user interface.

\section{Conclusions}

The utility of INCA as a tool with which to test hypotheses of nitrogen dynamics within catchments and investigate the likely response to global change across a broad range of river catchments has been demonstrated. The model, which is of intermediate complexity, uses data generally available throughout Europe and is able to represent the key factors and processes controlling nitrogen transport and storage in catchments in many contrasting climatic regions and with markedly different land-use.

INCA has also been proven successful as a method of scaling simulated data: the output generated from the $\left(1 \mathrm{~km}^{2}\right)$ component cell model is integrated across different land- 
use types to provide an estimate of the total flow and nitrogen mass delivered to the surface water. The nitrogen-cycling within the cell-model is differentiated between land-use types, based on the input data and process-parameterisation, and the output from the cell model can be checked against field and laboratory measurements and the output from other models. INCA produces daily estimates of flow and nitrogen concentrations in the land and in-stream components, and these daily data can be combined to provide seasonal and annual data at key points along the main channel of the river. The seasonal and annual simulated data are more accurate than the daily data given the uncertainty in input data, model structure and parameter values.

The results of the EU-INCA project are particularly satisfying in the following ways:

- Scientists with a wide range of expertise, knowledge and scientific outlook have examined the model for a wide range of catchments: there has been a major peer group scrutiny that models are rarely subjected to. Clearly there are differences in emphasis in modelling structures within and outside the programme group and issues such as complexity, full representation of process and the study of highly heterogeneous systems remain to be addressed (Hauhs et al., 1996; Kirchner et al., 2001; Beaujouan et al., 2002; Molénat and GascuelOdoux, 2002; Molénat et al., 2002). Nonetheless, the development of an updated INCA model (Wade et al., 2002a) has been highly successful in the development of a robust distributed model of intermediate complexity for nitrogen.

- Several leading research groups across Europe are now conversant with the use of the model in explorative, descriptive and predictive ways. They provide nucleation centres for new applications across a range of environmental and management settings.

- The model has been applied successfully in a wide range of environmental circumstances and used to evaluate the impacts of deposition, climate change and land-use on nitrogen export from the land, streamwater nitrogen concentrations and loads.

Though INCA represents an advance in the modelling of nitrogen in catchments throughout Europe, much work is still needed to develop a generic approach. The development of a generic model must remain the ultimate goal because to create a successful generic model equates to a sound hypothesis of $\mathrm{N}$ transport and storage. However, to provide a portfolio of the likely response to global change in the short-term, a more practical approach is recommended based on the use of a diversity and hierarchy of modelling approaches.
The development of INCA has reached a new and exciting phase. Having been applied initially in the UK and then modified for widespread use in European systems, the model is now to be chained with other approaches to simulate integrated river, lake and wetland systems throughout Europe. This chaining will be facilitated using the latest coding techniques and, therefore, the model will develop not only in a scientific sense, but in terms of a software development.

Spectral analysis of Plynlimon solute data implies that subsurface flow paths are highly heterogeneous, resulting in strong dispersion of chemical tracers (Kirchner et al., 2001): this is what is actually observed in the field (Neal, 1997). This result has important implications for the longterm dynamics of catchment response to contaminant inputs: in the long term, a highly dispersive transport system will be slower to flush itself of residual nutrients than a wellmixed 'box', the latter being the typical representation used in current catchment models, including INCA. However, new ideas of solute residence time and retardation factors with respect to the water movement are emerging based on spectral analysis (Feng et al., 2004); given that the INCA model is based on residence times, it may be possible to incorporate such ideas, possibly through using a residence time distribution. A key issue is obtaining sufficient data to show the 'symphonies' of dynamic responses that are now being identified and which need to be modelled (Kirchner et al., 2004).

The updated INCA model is now available for research and scenario modelling purposes from the Aquatic Environments Research Centre, University of Reading.

\section{Acknowledgements}

The authors thank the enthusiastic and stimulating contributions of the participants to the INCA modelling programme across Europe: Martin Ambruster, Susana Bernal, Annemarie Bastrup-Birk, Veronique Beaujouan, Andrea Butturini, Brian Cox, Nancy Dise, Patrick Durand, Nicola Flynn, Martin Forsius, Kirsti Granlund, Per Gundersen, Helen Jarvie, Øyvind Kaste, Lea Kauppi, JensJohann Langusch, Ahti Lepistö, Keith Lobley, Severine Machefert, Eugenia Marti, Egbert Matzner, Lucy O'Shea, Klaasjan Raat, Katri Rankinen, Laurent Ruiz, Fransesc Sabater, Richard Skeffington, Albert Tietema, Wim Wessell and Paul Whitehead.

The authors and the participants of the INCA project are very grateful to Drs Hartmut Barth, Andrea Tilche and Christos Fragakis for providing support, originally under the EU research programme Integrated Nitrogen Model for European Catchments: contract number EVK1-1999-00011, 
and now continued under 'Euro-limpacs", contract number GOCE-CT-2003-505540. The authors are most appreciative of the editorial contribution by Jim McCulloch, whose skills and drive are both commendable and remarkable.

\section{References}

Avila, A., Rodrigo, A. and Rodà, F., 2002. Nitrogen circulation in a Mediterranean holm oak forest, La Castanya, Montseny, north eastern Spain. Hydrol. Earth Syst. Sci., 6, 551-557.

Bastrup-Birk, A. and Gundersen, P., 2004. Water quality improvements from afforestation in an agricultural catchment in Denmark illustrated with the INCA model. Hydrol. Earth Syst. Sci., 8, 764-777.

Beaujouan, V., Durand, P., Ruiz, L., Aurousseau, P. and Cotteret, G., 2002. A hydrological model dedicated to topography-based simulations of nitrogen transfer and transformation: rationale and application to the geomorphology-denitrification relationship. Hydrol. Process., 16, 493-507.

Bernal, S., Butturini, A., Riera, J.L., Vázquez, E. and Sabater, F., 2004. Calibration of the INCA model in a Mediterranean forested catchment: the effect of hydrological inter-annual variability in an intermittent stream. Hydrol. Earth Syst. Sci., 8, 729-741.

Beven, K.J., 2000. Uniqueness of place and process representations in hydrological modelling. Hydrol. Earth Syst. Sci., 4, 203213.

Boorman, D.B., 2003. Climate, Hydrochemistry and Economics of Surface-water Systems (CHESS): adding a European dimension to the catchment modelling experience developed under LOIS. Sci. Total Envir., 314-316, 411-437.

Burt, T.P., Heathwaite A.L. and Trudgill, S.T., 1993. Nitrate; processes, patterns and management. Wiley, Chichester, UK, $444 \mathrm{pp}$.

Butturini, A. and Sabater, F., 2002. Nitrogen concentrations in a small Mediterranean stream: 1. Nitrate 11 Ammonium. Hydrol. Earth Syst. Sci., 6, 539-550.

Butturini, A., Bernal, S., Sabater, S. and Sabater, F., 2002. The influence of riparian-hyporheic zone on the hydrological responses in an intermittent stream. Hydrol. Earth Syst. Sci., 6, $515-525$.

Cosby, B.J., Wright, R.F., Hornberger, G.M. and Galloway, J.N. 1985. Modelling the effects of acid deposition: assessment of a lumped parameter model of soil water and streamwater chemistry. Water Resour. Res., 21, 51-63.

Davies, H. and Neal, C., 2004. GIS based methodologies for assessing nitrate, nitrite and ammonium distributions across a major UK basin, the Humber. Hydrol. Earth Syst. Sci., 8, 823833.

Dillon, P.J., Scheider, W.A., Reid, R.A. and Jeffries, D.S., 1994. Lakeshore capacity study: Part I- Test of effects of shoreline development on the trophic status of lakes. Lake Reservoir Manage., 8, 121-129.

Durand, P., 2004. Simulating nitrogen budgets in complex farming systems using INCA: calibration and scenario analyses for the Kervidy catchment (W. France). Hydrol. Earth Syst. Sci., 8, 793-802.

Feng, X.H., Kirchner, J.M. and Neal, C., 2004. Measuring catchment-scale chemical retardation using spectral analysis of reactive and passive chemical tracer time series. J. Hydrol., 292, 296-307.

Fisher, J. and Acreman, M.C., 2004. Wetland nutrient removal: a review of the evidence. Hydrol. Earth Syst. Sci., 8, 673-685.
Flynn, N.J., Paddison, T. and Whitehead, P.G., 2002. INCA modelling of the Lee system: Strategies for the reduction of nitrogen loads. Hydrol. Earth Syst. Sci., 6, 467--483.

Gallart, F., Llorens, P., Latron, J. and Regüés, D., 2002. Hydrological processes and their seasonal controls in a small Mediterranean mountain catchment in the Pyrenees. Hydrol. Earth Syst. Sci., 6, 527-537.

Granlund, K. Rankinen, K. and Lepistö, A., 2004. Testing the INCA model in a small agricultural catchment in southern Finland. Hydrol. Earth Syst. Sci., 8, 717-728.

Hauhs, M., Neal, C., Hooper, R. and Christophersen, N. (Eds.), 1996. Modelling in environmental studies. Sci. Total Envir., 183, $185 \mathrm{pp}$.

Heathwaite, A.L., Burt, T.P. and Trudgill, S.T., 1993. Overview the nitrate issue. In: Nitrate; processes, patterns and management, T.P. Burt, A.L. Heathwaite and S.T. Trudgill, (Eds.), Wiley, Chichester, UK, 3-21.

Hewett, C.J.M., Quinn, P.F., Whitehead, P.G., Heathwaite, A.L. and Flynn, N.J., 2004. Towards a Nutrient Export Risk Matrix Approach to Managing Agricultural Pollution at Source. Hydrol. Earth Syst. Sci., 8, 834-845.

Hill, T., 2000. Dynamic Modelling and Analysis of Hydrochemistry in Upland Forested Catchments. PhD Thesis, University of Reading. Aquatic Environments Research Centre, The University of Reading, Department of Geography, Whiteknights, P.O. Box 227, Reading, RG6 6AB, UK. 199pp.

Jakeman, A.J. and Hornberger, G. M., 1993. How much complexity is warranted in a rainfall-runoff model?. Water Resour. Res., 29, 2637-2649.

Jarvie, H.P., Wade, A.J., Butterfield, D., Whitehead, P.G., Tindall, C.I., Virtue, W.A., Dryburgh W. and McGraw, A., 2002. Modelling nitrogen dynamics and distributions in the River Tweed, Scotland: an application of the INCA model. Hydrol. Earth Syst. Sci., 6, 433-453.

Johnes, P.J., 1996. Evaluation and management of the impact of land use change on the nitrogen and phosphorus load delivered to surface waters: the export coefficient modelling approach. $J$. Hydrol., 183, 323-349.

Kaste, O. and Skjelkvåle, B.L., 2002. Nitrogen dynamics in runoff from two small heathland catchments representing opposite extremes with respect to climate and $\mathrm{N}$ deposition in Norway. Hydrol. Earth Syst. Sci., 6, 351-362.

Kaste, Ø., Rankinen, K. and Lepistö, A., 2004. Modelling impacts of climate and deposition changes on nitrogen fluxes in northern catchments of Norway and Finland. Hydrol. Earth Syst. Sci., 8, 778-792.

Kennedy, M.P. and Murphy, K.J., 2004. Indicators of nitrate in wetland surface and soil-waters: interactions of vegetation and environmental factors. Hydrol. Earth Syst. Sci., 8, 663-672.

Kirchner, J.W., Feng, X.H. and Neal C., 2001. Catchment-scale advection and dispersion as a mechanism for fractal scaling in stream tracer concentrations. J. Hydrol., 254, 81-100.

Kirchner, J.M., Feng, X., Neal, C. and Robson, A.J., 2004, The fine structure of water-quality dynamics: the (high-frequency) wave of the future. Hydrol. Process., 18, 1353-1359.

Kros, J., Tietema, A., Mol-Dijkstra, J.P. and de Vries, W., 2004. Quantification of nitrate leaching from forest soils on a national scale in The Netherlands. Hydrol. Earth Syst. Sci., 8, 813-822.

Langusch, J.J. and Matzner, E., 2002a. N fluxes in two nitrogen saturated forested catchments in Germany: Dynamics and modelling with INCA. Hydrol. Earth Syst. Sci., 6, 383-394.

Langusch, J.J. and Matzner, E., 2002b. Long-term modelling of nitrogen turnover and critical loads in a forested catchment using the INCA model. Hydrol. Earth Syst. Sci., 6, 395-402.

Likens, G.E., 2004. Biogeochemistry: some opportunities and challenges for the future. Water Air Soil Pollut.: Focus, 4, 5-24. 
Limbrick, K.J., 2002. Estimating daily recharge to the Chalk aquifer of Southern England - a simple methodology. Hydrol. Earth Syst Sci., 6, 485-495.

Limbrick, K.J., Whitehead, P.G., Butterfield, D. and Reynard, N., 2000 . Assessing the potential impacts of various climate change scenarios on the hydrological regime of the River Kennet at Theale, Berkshire, south-central England, UK: an application and evaluation of the new semi-distributed model, INCA. Sci. Total Envir., 251/252, 539-556.

Lischeid, G. and Langusch, J., 2004. Comparative simulation of the nitrogen dynamics using the INCA model and a neural network analysis: implications for improved nitrogen modelling. Hydrol. Earth Syst. Sci., 8, 742-750.

Machefert, S.E. and Dise, N.B., 2004. Hydrological controls on denitrification in riparian ecosystems. Hydrol. Earth Syst. Sci., 8, 686-694.

Machefert, S.E., Dise, N.B., Goulding K.W.T. and Whitehead, P.G., 2002. Nitrous oxide emission from a range of land-uses across Europe. Hydrol. Earth Syst. Sci., 6, 325-337.

Molénat, J. and Gascuel-Odoux, C., 2002. Modelling flow and nitrate transport in groundwater for the prediction of water travel times and of consequences of land use evolution on water quality. Hydrol. Process., 16, 479-492.

Molénat, J., Durand, P., Gascuel-Odoux, C., Davy, P. and Gruau, G., 2002. Mechanisms of nitrate transfer from soils to stream in an agricultural watershed of French Brittany. Water Air Soil Pollut., 133, 161-183.

Neal, C., 1997. A view of water quality from the Plylimon watershed. Hydrol. Earth Syst. Sci., 1, 743-753.

Neal, C., 2002a. Nutrient concentrations and fluxes for podzolic and gley soils at Plynlimon, mid-Wales: implications for modelling inorganic nitrogen and phosphorus in upland UK environments. Hydrol. Earth Syst. Sci., 6, 403-420.

Neal, C., 2002b. Assessing environmental impacts on stream water quality: the use of cumulative flux and cumulative flux difference approaches to deforestation of the Hafren Forest, midWales. Hydrol. Earth Syst. Sci., 6, 421-431.

Neal, C., Whitehead, P.G., and Flynn, N., 2002. INCA: summary and conclusions. Hydrol. Earth Syst. Sci., 6, 607-616.

Neal, C., Skeffington, R.A., Neal, C., Wyatt, R., Turner, H., Hill, L. and Hewitt, E., 2004a. Rainfall and runoff water quality of the Pang and Lambourn, tributaries of the River Thames, south eastern England. Hydrol. Earth Syst. Sci., 8 , 601-613.

Neal, C., Jarvie, H.P., Wade, A.J., Neal, M., Wyatt, R., Turner, H., Hill, L. and Hewitt, E. 2004. The water quality of the LOCAR Pang and Lambourn catchments. Hydrol. Earth Syst. Sci., 8, 614-635.

Raat, K.J., Draaijers, G.P.J., Schaap, M.G., Tietema, A. and Verstraten, J.M., 2002. Spatial variability of throughfall water and chemistry and forest floor water content in a Douglas fir forest stand. Hydrol. Earth Syst Sci., 6, 363-374.

Raat, K.J., Vrugt, J.A., Bouten, W. and Tietema, A., 2004. Towards reduced uncertainty in catchment nitrogen modelling: Quantifying the effect of field observation uncertainty on model calibration. Hydrol. Earth Syst. Sci., 8, 751-763.

Rankinen, K., Lepisto, A. and Granlund, K., 2002. Hydrological application of the INCA (Integrated Nitrogen in Catchments) model with varying spatial resolution and nitrogen dynamics in a northern river basin. Hydrol. Earth Syst Sci., 6, 339-350.

Rankinen, K., Kaste, Ø. and Butterfield, D., 2004a. Adaptation of the Integrated Nitrogen Model for Catchments (INCA) to seasonally snow-covered catchments. Hydrol. Earth Syst. Sci., 8, 695-705.
Rankinen, K., Karvonen, T. and Butterfield, D., 2004b. A simple model for predicting soil temperature in snow-covered and seasonally frozen soil: model description and testing. Hydrol. Earth Syst. Sci., 8, 706-716.

Ruiz, L., Abiven, S., Durand, P., Martin, C., Vertes, F. and Beaujouan, V., 2002a. How nitrate concentration in stream water is affected by agricultural practices in small agricultural catchments. I - Annual nitrogen budgets for six small catchments in Western Brittany (France). Hydrol. Earth Syst. Sci., 6, 497505.

Ruiz, L., Abiven, S., Martin, C., Durand, P., Beaujouan, V. and Molenat, J., 2002b. How nitrate concentration in stream water is affected by agricultural practices in small agricultural catchments. II - Temporal variations and mixing processes. Hydrol. Earth Syst. Sci., 6, 507-513.

Scholefield, D., Lockyer, D.R., Whitehead, D.C. and Tyson, K.C., 1991. A model to predict transformations and losses of nitrogen in UK pastures grazed by beef-cattle. Plant Soil, 132, 165-177.

Skeffington, R., 2002. European nitrogen policies and nitrate in rivers and the use of the INCA model. Hydrol. Earth Syst. Sci., 6, 315-324.

Smith J.U., Bradbury, N.J. and Addiscott, T.M., 1996. SUNDIAL: A PC-based system for simulating nitrogen dynamics in arable land. Agron. J., 88, 38-43.

Snook, D.L. and Whitehead, P.G., 2004. Water quality and ecology of the River Lee: Mass balance and a review of the temporal and spatial data. Hydrol. Earth Syst. Sci., 8, 636-650.

Stanners, D. and Bourdeau, P. (Eds), 1995. Europe's Environment: The DobYíšs Assessment. European Environment Agency: office for official publications of the European Communities (Luxembourg), 676pp.

Tietema, A., 2004. WANDA, a regional dynamic nitrogen model (With Aggregated Nitrogen DynAmics) for nitrate leaching from forests. Hydrol. Earth Syst. Sci., 8, 803-812.

Tietema, A., Mol-Dijkstra, J.P., Kros, J. and de Vries, W., 2002. Dynamic nitrogen critical loads during forest stand development in a Douglas fir forest analysed with two nitrogen models SMART2 and MERLIN. Hydrol. Earth Syst. Sci., 6, 375-382. Vagstad, N., Stålnacke, P., Andersen, H.-E., Deelstra, J., Jansons, V., Kyllmar, K., Loigu, E., Rekolainen, S. and Tumas, R., 2004. Regional variations in diffuse nitrogen losses from agriculture in the Nordic and Baltic region. Hydrol. Earth Syst. Sci., 8, 651-662.

Wade A.J., Durand, P., Beaujouan, V., Wessel, W.W., Raat, K.J., Whitehead, P.G., Butterfield, D., Rankinen, K. and Lepisto A., 2002a. A nitrogen model for European catchments: INCA, new model structure and equations. Hydrol. Earth Syst Sci., 6, 559582.

Wade, A.J., Whitehead, P.G., and O'Shea L.C.M., 2002b. The prediction and management of aquatic nitrogen pollution across Europe: An introduction to the Integrated Nitrogen in European Catchments project (INCA). Hydrol. Earth Syst. Sci., 6, 299313.

Wade, A.J., Whitehead, P.G., Hornberger, G.M. and Snook, D.L., 2002c. On modelling the flow controls on macrophyte and epiphyte dynamics in a lowland permeable catchment: the River Kennet, southern England. Sci. Total Envir., 282/283, 375-393.

Wade, A.J., Whitehead, P.G. and Butterfield, D., 2002d. The Integrated Catchments Model of Phosphorus Dynamics (INCAP), a new approach for multiple source assessment in heterogeneous river systems: model structure and equations. Hydrol. Earth Syst Sci., 6, 583-606. (See also Errata. Hydrol. Earth Syst. Sci., 8, 859.) 
Wade, A.J., Neal, C., Whitehead, P.G. and Flynn, N., In press. Modelling nitrogen fluxes from the land to the coastal zone in European systems: a perspective from the INCA project. $J$. Hydrol.

Whitehead, P.G., Wilson, E.J. and Butterfield, D., 1998a. A semidistributed Integrated Nitrogen model for multiple source assessment in Catchments (INCA): Part I - model structure and process equations. Sci. Total Envir., 210/211, 547-558.

Whitehead, P.G., Wilson, E.J., Butterfield, D. and Seed, K., 1998 b. A semi-distributed Integrated Nitrogen model for multiple source assessment in Catchments (INCA): Part II - application to large river basins in south Wales and Eastern England. Sci. Total Envir., 210/211, 559-584.

Whitehead, P.G., Johnes, P.J. and Butterfield, D., 2002a. Steady state and dynamic modelling of nitrogen in the River Kennet: impacts of land use change since the 1930s. Sci. Total Envir., 283-284, 417-434.
Whitehead, P.G., Lapworth, D.J., Skeffington, R.A. and Wade A.J., 2002b. Excess nitrogen leaching and $\mathrm{C} / \mathrm{N}$ decline in the Tillingbourne catchment, Southern England: INCA process modelling for current and historic time series. Hydrol. Earth Syst. Sci., 6, 455-466.

Wright, R.F. and Rasmussen, L. (Eds.), 1998a The whole ecosystem experiments of the NITREX and EXMAN projects. Forest Ecol. Manage., 101. 363pp.

Wright, R.F. and Rasmussen, L., 1998b. Introduction to the NITREX and EXMAN projects. Forest Ecol. Manage., 101, 1-8. 